\title{
THE TRIBUTARY RELATIONS BETWEEN CHINA'S SONG DYNASTY AND VIETNAM'S DINH, LE AND LY DYNASTIES: EFFECTS ON THEIR POLITICAL SUSTAINABILITY
}

\author{
Ku Boon Dar \\ Universiti Sains Malaysia (USM)
}

\begin{abstract}
This article reviews the history of China-Vietnam's relations from the time of the independence of Vietnam in 939 until the reign of the Ly dynasty $(1010-1225)$. It focuses on how China and Vietnam established a relationship based on the tributary system and how far these early ties had affected the political continuity of the Chinese Song and the Vietnamese Dinh, Le and Ly dynasties. In addition, this is an attempt to analyse Vietnam's view on China's World Order in its relationship with China. It also illustrates that China's "all under heaven" concept suggests a sense of unity in the Chinese world, derived from the moral conformity of its society; and how during the Song dynasty, China based itself on this moral conformity when it set out to develop a relationship with its neighbours, in this case, Vietnam.
\end{abstract}

Keywords: Sino-Vietnamese Relations, Tributary System, Song Dynasty, Ly Dynasty

\section{Introduction}

Vietnam had long been a Chinese tributary and was, in fact, the earliest country in Southeast Asia to establish ties with China. The relationship had been established since $111 \mathrm{BC}$ and it had an accustomed place in the Sinocentric East Asian system of international relations. The growth of Vietnam was closely linked to the rise and fall of the Chinese dynasties and the situation which prevailed in China. For example, the decline of the Tang dynasty $(618-907)$ in the 8th century made an impact not only on China but also Vietnam. The Tang's collapse which threw the country into chaos, gave way to the rise of the states known as Wudai Shiguo (The Period of Five Dynasties and Ten Kingdoms, 906-960) in China. Vietnam also took advantage of this political uncertainty to free itself from China's clutches after having been colonized by it for over a millennium. Ngo Quyen (938-944) successfully forced China's military in Bach Dang situated in the north of Vietnam which covers the district of Ha Bac, Hai Hung and Quang Ninh, to withdraw in 939 and subsequently, established the Ngo dynasty (939-968).

Joseph Buttinger suggests that the Vietnamese victory of 939 was largely attributed to the persistence of the Vietnamese in their struggle for independence and the political disintegration of China's Tang dynasty. ${ }^{1}$ Thus, this article examines the relationship between the two countries, or rather specifically the two dynasties, to assess the extent to which Vietnam, a former colonial state, could successfully maintain its sustainability and continuity after its change of status. There is also the question of how far the Song dynasty (China) was willing to recognise the independence of the Ngo dynasty (Vietnam) amidst the turmoil in China. 


\section{Relationship of Chinese Song Dynasty With Vietnamese Ngo and Dinh Dynasties}

Vietnam's (read: Giao Chi交趾) independence in 939 put an end to the period of Chinese imperial domination but it remained in a fragile state. ${ }^{2}$ The Ngo dynasty (939965) was unable to control the local chiefs known as Hung Vuong or Su Quan because the ruling power was still in their hands. Since Ngo Quyen failed to gain acknowledgement of his legitimacy as a ruler from China, he could not get the unanimous support of the local authorities. Furthermore, the Ngo dynasty was still recorded as Ngoai Ky (not officially confirmed as a dynasty in Vietnamese history) because he was still known as a 'military governor', and not a king (vuong). ${ }^{3}$ These local chiefs possessed their own territories and constantly tried to dominate one another. Ngo Quyen died at the age of 46 before he had time to consolidate his position; Vietnam was little more than a protectorate of the Chinese empire. China, on its part, viewed the Sino-Vietnamese tributary relations as more of a relationship of the central government (China) vis-à-vis the local government (Vietnam). Therefore, local political institutions were not interfered with, and authority still lay in the hands of the local feuding chiefs.

Vietnam (read: Thap Nhi Su Quan十二使君), experiencing internal conflicts among its independent chiefs, became disunited. When the last heir of the Ngo dynasty, Thien-Sach Vuong died in 967, the conflicts exacerbated to the extent that the era was known as "The Twelve Lords Rebellion". ${ }^{4}$ Amidst the rivalry, Dinh Bo Linh $(968$ 979) emerged victorious to unite Vietnam as a powerful entity known as Dai Co Viet. Dinh Bo Linh was originally a general in Tran Lam's military and one of the twelve Lords (Su Quan). ${ }^{5}$ In 968, he founded the Dinh dynasty (968-980), shifted the capital from Lo Loa to Hoa Lu which located in Ninh Binh and declared himself as Dinh Tien Hoang De (The First August Emperor Dinh) with his reign of Thai Binh inaugurated in $970 .^{6}$

Understandably, Dinh Bo Linh did not want to confront the Song armies unnecessarily, and so he sent his eldest born, Dinh Lien and ambassadors of goodwill with tributes of gold bars, rhinoceros horns, elephant tusks and fragrances to have his reign of Thai Binh recognised and inaugurated by Emperor Song Taizu (960-976). ${ }^{7}$ Tributes were then continuously sent to China from Dai Co Viet, as Vietnam was called at that time (See Table 1).

Table 1: Vietnamese Emissary Missions (of the Dinh Dynasty) to China

\begin{tabular}{|c|c|c|}
\hline Year & Emmisaries & Mission \\
\hline 975 & Trinh Tu & $\begin{array}{l}\text { Presented rhinoceros horns, elephant tusks, fragrances and } \\
\text { gold bars to the Song dynasty. }\end{array}$ \\
\hline 975 & $\begin{array}{l}\text { Zu Wangyan } \\
\text { (from China) }\end{array}$ & Attended Dinh Lien's coronation as Giao Chi Quan Vuong \\
\hline 976 & $\begin{array}{l}\text { Nguyen Vien } \\
\text { Thai }\end{array}$ & Delivered condolences on the death of Emperor Song Taizu \\
\hline 977 & $\begin{array}{l}\text { Nguyen Vien } \\
\text { Thai }\end{array}$ & $\begin{array}{l}\text { Delivered congratulatory speech at the coronation of Emperor } \\
\text { Song Taizong }\end{array}$ \\
\hline
\end{tabular}

Source: Songshi (History of the Song Dynasty), Vol. 488, Lie Zhuan (Collective Biographies), No. 247, Wai Guo Shi: Jiaozhi (Foreign Countries: Giao Chi) 


\section{Song-dinh Tributary Terms and Rationale}

Both the Dinh and the Song dynasties then worked out the basis for their mutual relations to transform Vietnam's position into that of a vassal or tributary state within the Chinese orbit. Vietnam acknowledged itself a tributary of China, with the understanding that it would not be occupied by the Chinese troops or subjected to Chinese administration. It also agreed to send tribute missions to Kaifeng (central China's Henan province), the Chinese capital.

In return, Emperor Song Taizu (960-976) acknowledged and nominated Dinh Bo Linh (968-979) as Jiaozhi junwang or Giao Chi quan vuong (Commandery Prince of Jiaozhi) which signified the recognition of Vietnam as one of his protectorates and not as a colonised state. ${ }^{8}$ Brantly Womack states that as the Song Dynasty consolidated its rule in the south in 973, it anticipated the difficulty of reconquering a territory that had withstood the Chinese army, and it was clear that the dynasty's major military problems lay in the north. ${ }^{9}$ Moreover, being newly crowned, Emperor Song Taizu knew he had to approach the neighbouring countries including Vietnam with diplomacy. He also realised that the spread of Confucianism to all its protectorates could help China gain their loyalty. ${ }^{10}$ It had been centuries of Chinese practice to employ the rich symbolism of the ceremonial forms and perhaps above all, the use of moralistic Confucian political terminology in formal contacts between China and her tributaries including Vietnam as they served to soften the outline of the realities of power which lay beneath.

Finally, Vietnam promised to reciprocate by presenting tributes to China every three years, using the lunar calendar; and giving reports on Vietnam's progress. China promised to protect Vietnam when required and to acknowledge it as its protectorate. ${ }^{11}$ Dinh Bo Linh was the first to be conferred the title of Giao Chi Quan Vuong (King of Giao Chi) as the previous rulers were only given the title 'Military Governor of Giao Chi'. ${ }^{12}$ Although acknowledged as an independent country, Vietnam was still under the Emperor's control in line with the Chinese cosmopolitan space of Wufu (Five Domains) as specified below:

"Dian Domains in Five Hundred Miles: People in the nearest area, within one hundred miles away from the capital should render their service by submitting all their harvests. Other contributions required were eared millet from those in the region of two hundred miles away from the capital; hard-skinned millet from those, three hundred miles away; raw millet from the area, four hundred miles away and refined millet from the area, five hundred miles away. Hou Domains in Five Hundred Miles away from the Extreme of Dian Domains: People in the nearest area, one hundred miles away from the extreme of the Dian s Domains, should render their transport service to the emperor, those in the area, two hundred miles away were to contribute to their dukedom while people in the area three hundred miles away should gather intelligence of danger."13

The above Dian Domains stipulations categorized according to geographical location from China's orbit, reflected the Chinese Emperor's perception of himself as the ruler whose sovereignty and greatness must always be acknowledged by Vietnam. In this idealized, concentric structure of the Five Domains, the king's capital was not only the political center but also the pivot of the cosmic-social order. ${ }^{14}$ 
James Anderson argues that, for Dinh Bo Linh the tributary relationship would help to strengthen the position of the Dinh dynasty in the eyes of the Vietnamese as China's recognition verified the dynasty's political legitimacy and confirmed his validity as a ruler. ${ }^{15}$ Indeed, the period of the Song dynasty in China and the Dinh dynasty (968-980) in Vietnam had drawn up a new phase in the Sino-Vietnamese diplomatic relations based on the tributary system that was established centuries ago. The difference is that it signalled the start of a real country-to-country- contact model of tributary relationship between the two countries.

\section{Song Dynasty's Move to Recapture Vietnam and its Consequences}

In 979, Dinh Bo Linh was assassinated by Do Thich (? -979), a guard who tried to usurp the throne. After three days, the coup d'etat was ended by Nguyen Bac. Do Thich's bones were crushed; his body was chopped for the Vietnamese to chew. ${ }^{16}$ Dinh Bo Linh was then succeeded by his second prince Dinh Phe De (979-980) who was only six years old then. After killing Do Thich, Nguyen Bach tried to overthrow Dinh Phe De. Angered upon hearing the news, Emperor Song Taizong (976-997) launched an attack on Vietnam. ${ }^{17}$

The Song Emperor decreed, "Dispatch troops to supress the rebellion, as it is a rational measure. By suppressing the protest movement, the power struggle that often happens can be contained." In the meantime, the Commissioner in Guangxi reported that:

"The family of Dinh Bo Linh was being set up by rebels, revolts seemed to occur everywhere (in Vietnam), and it was increasingly difficult for the people to accumulate a fortune by relying solely on farming. Despite these troubled times, Vietnam's ruling dynasty had been sending a caravan carrying tributes to China's court periodically.' 18

In view of the above report, China believed that it was important to have control of the situation in Vietnam in its capacity as the latter's overlord. It also believed that only Vietnam's legitimate heir to the throne, recognized by China could be appointed as the ruler in Vietnam. Hence, in 981, China deployed its military forces led by General Hou Renbao (侯仁宝 (?-981) to Vietnam to suppress the coup, the basic reason of which was to safeguard the sovereignty of the Dinh dynasty, its vassal. ${ }^{19}$ However, to what extent is this a fact? According to Xu Zizhi Tongjian Changbian's (Extended Continuation to Zizhi Tongjian) record, ${ }^{20}$ before the advance of the forces of the Song dynasty to Vietnam roughly around 980, the emperor had summoned an officer in Yongzhou (district near modern day Nanning), Hou Renbao to discuss with the king the necessary preparation. However, he was stopped by the prime minister, Lu Duoxun (934-985) who believed that:

"Giao Chi (Jiaozhou) is on the verge of chaos which is a sign from heaven. Our kingdom (China) can send troops to attack by surprise; Nonetheless, if officials from the border are instructed to come to the capital, it is concerned that the plan may be revealed and they (Vietnam) will learn about it. They (Vietnam) will be prepared and will besiege all paths including the water route. This will make it difficult for our forces to advance (Song).,"21 
Later, in the seventh month of the same year, Emperor Song Taizong went ahead with his plan and ordered Lu Duoxun to capture Vietnam. This attack was no longer viewed as just the intention of China to preserve the integrity of the Song dynasty as the overlord of its protectorate, Vietnam but also clearly its intention to conquer Vietnam completely in order to absorb the country into its colonies. Emperor Song Taizong believed that because it was then the golden period of the Song dynasty, and as the superior state, China would not simply tolerate the total independence of Vietnam. Should that happen, it would mean that Vietnam could slip out of China's grip as what had happened in the past when China's political upheaval was taken advantage of by Vietnam to declare its own independence.

In 980, the Song dynasty mounted an assault on Vietnam by land and water. However, the lack of patience and thorough planning cost China dearly. The Song dynasty had underestimated Vietnam's military capabilities, thinking that the internal conflicts in Vietnam would have affected its army's readiness and strength. Although China had the upper hand initially, unfortunately, miscommunication between its water and land armies caused the battle timing to go wrong. In addition to that, at the later stage, its soldiers, not acclimatised to the surroundings, died in large numbers, causing the mission to fail.

The Song dynasty, albeit reluctantly, accepted the defeat and gave up the idea of retaking Vietnam. A system called Jimi zhi (羈縻制) had to be introduced to Vietnam instead. The Jimi system was an administrative model unit in China which was introduced to every military leader either militarily subdued or self-subdued and naturalized. These groups received orders directly from the central power in China although it allowed them the freedom to retain their names as long as they submitted to the orders of the Chinese emperor. Indeed, the Jimi System was seen as a system which was necessary at the time because China was beginning to lose control of Vietnam. ${ }^{22}$

\section{Relationship of Chinese Song Dynasty with Vietnamese Le Dynasty}

Although Le Hoan (941-1005), the Vietnamese Commander-in-Chief, succeeded in repulsing the Song dynasty invasion, he was forced to submit to China because he realised that Vietnam's military power was limited. As he was also worried about the strength of the Song dynasty, he planned a strategy to evade an attack from China. Accordingly, in 938, in the name of Dinh Toan, he sent an envoy to China to seek the pardon of the Song Emperor. Le Hoan who had actually declared himself as Giao Chi Vuong (King of Giao Chi). He claimed that'Dinh Toan and his mother had led an army and the people against China. They appointed Le Hoan as the new ruler. ${ }^{23}$

Masquerading as Dinh Xuan, Le Hoan manipulated the situation to obtain China's recognition of his validity as the new ruler in Vietnam. He justified the advance of Vietnam's military against the Dinh dynasty with the excuse, among others, that he acted out of a desire to serve the people of Vietnam who lived in depravity under the Dinh dynasty.

However, the Song dynasty rejected Le Hoan's explanation and instead, the latter was given an ultimatum. "Dinh Xuan will continue to rule Vietnam and be appointed as general with Le Hoan as his deputy; or send Dinh Xuan and his mother as well as all their family members to China. As soon as they arrive in China, Le Hoan will be given jiemao (a staff attached with the tail of a yak) as appointment of power to rule Vietnam." 24

Obviously, Le Hoan was unable to fullfill China's request because in truth he had proclaimed himself as Vietnam's ruler while the Dinh dynasty's family was killed 
in the coup. ${ }^{25}$ Emperor Song Taizong's offer was ignored, as confirmed in Songshi (History of the Song Dynasty) that 'at that time, Le Hoan who had already taken over the Vietnamese territory, did not accept the order from China. ${ }^{26}$

Meanwhile, in the years 982 and 983, Le Hoan raided Champa twice. His strategy was to first 'capture 39 generals from Champa meant to be presented to China and then, to inform the Song dynasty of his victory in defeating the Champa soldiers and capturing millions of war prisoners. ${ }^{27}$ Generally, Le Hoan would inform China of everything that happened in Vietnam for the fact that China was the state's overlord. However, it was apparently his cunning tactics to use the information to serve the Song ruler a warning that Vietnam's military was strong and ready. In other words, it conveyed the idea to China that Vietnam was even able to defeat Champa, an old empire which once had control of the centre and south of Vietnam in the $7^{\text {th }}$ century. Hence, to defeat the Song dynasty which was in recovery after the civil war would not be a problem to Vietnam. This appeared to be a reminder to the Song dynasty to relinquish its ambition to recapture Vietnam. The Song dynasty had the same thought when it decided to acknowledge Le Hoan as ruler and to terminate its support for the Dinh's successor. The recognition, however, was limited to Le Hoan's validity as King of Giao Chi who founded the Le Dynasty in Vietnam in 993.

This has led Keith Taylor to consider that Le Hoan's succession to the throne was achieved through manipulation which deterred the Song dynasty from recapturing Vietnam. Le Hoan had also managed to unite the Vietnamese to put aside their misunderstanding and fight against the advancing Song forces. After having defeatad the Song army, he successfully established his kingdom which lasted until the 14th century. ${ }^{28}$

Despite Le Hoan's (941-1005) successes in warding off China's military attack followed by founding the Early Le dynasty (980-1009), he offered to remain loyal to China. He was the Commander-in-chief in Dinh Bo Linh's military and then acted as regent to the king's successor, Dinh Phe De (974-1001) whom he later dethroned his victory in chasing out China from Vietnam had garnered him support from the court officials. Moreover, after deposing Dinh Phe De, he had the blessings of the queen, to ascend to the throne and establish the Early Le dynasty. He declared himself as the ruler, Dai Co Viet with the title Thien Phuc and set up his capital in Hoa Lu. $^{29}$

In 983, the first envoy was sent to China to appeal for his coronation. It had been the belief of the rulers of Vietnam that only through receiving a title from the Chinese dynasties could they have the political backing to strengthen their position within the country. Only with the title bestowment by China could the people be convinced that they were the legitimate rulers. At the same time, China could also show its suzerain position and lofty prestige as the 'Heavenly Kingdom'. That is why, Vietnamese rulers of the past generations had all along asked for title investitures from China.

\section{Song - le Tributary Terms and Rationale}

Not long after the Dinh dynasty was established, Vietnam was actively sending tributes to seek from China title bestowment, andacknowledgment of its sovereignty. The Song dynasty first conferred on Dinh Lian the title Tinh Hai quan Tiet do su (Jinghai Regiments) and then Protectorate General of Annam. However, for Dinh Bo Linh, it was decided that he 'could be granted the title Giao-chi Quan Vuong or King of Giao Chi Prefecture. It was the first time in the history of China that a ruler of Vietnam was given the title 'king'. ${ }^{30}$ 
On the surface, this showed that the Song dynasty had treated the Dinh dynasty rather leniently despite its involvement in the domestic anarchy that ended the Ngo dynasty. However, this was not the real picture. China had to unite the country and strengthen its political power. Its strong opponent, Champa, also posed a threat. Under these circumstances, it had no choice but to show leniency, with the aim of temporarily stabilising Vietnam to withstand external threats to provide China the respite necessary for gathering enough strength to resolve the situation. At the same time, the Dinh dynasty, in order to ensure its own safety, had actively sent tributes to maintain its tributary relationship with China which would then have no valid reason to dispatch troops to Vietnam.

In contrast, when it was Le Hoan's turn to request for title investiture, the Song dynasty's initial decision was to reject him and instead counter propose absolute submission from him. It was because the Song dynasty was unwilling to accept its loss in the war while still harbouring the desire to reclaim Vietnam; besides as the suzerain lord of Vietnam, China had been unable to protect its vassal - the Dinh dynasty. The rejection of Le Hoan's request could in a way help to salvage some of its reputation. Eventually, when the Song ruler realized that Vietnam was getting stronger, he was compelled to acknowledge Le Hoan in 986 but only appointed him as Annan Duhu (Superior Prefect of Annam). It was only at the end of 993 after the Song Emperor was convinced that he would remain loyal, was he appointed Giao Chi Quan Vuong (King of Giao Chi) with the title Nam Binh Vuong (King of the Southern Pacified Region). To secure recognition and forgiveness from the Song emperor, Le Hoan sent five tributebearing envoys to China between 982 and $994 .{ }^{31}$

In exchange for the acknowledgement, the Song dynasty hoped that Le dynasty would help to control and coordinate the foreigners around Vietnam and to spread the teachings of Confucianism around the south of China. ${ }^{32}$ This was due to China's perception that Vietnam was a primitive country with indigenous tribes or Nanman (Southern Barbarians) located to the south west of China. ${ }^{33}$

\section{Relationship of Chinese Song Dynasy and Vietnamese Ly Dynasty}

After Le Hoan's death in 1005, there was another fight for the throne among his heirs. Upon hearing this, Emperor Song Zhenzong (998-1022) sent a message to the princes advising them to stop fighting among themselves. ${ }^{34}$ Although the power struggle did not stop, there was nothing China could do as they should not be meddling in the internal affairs of their protectorate seeing that the conflict was among the legitimate heirs as argue by Guo Zhenduo and Zhang Xiaomei. ${ }^{35}$ By 1010, the Early Le dynasty (980 - 1009) came to an end when Le Long Dinh (1005-1009), its last ruler died at the age of 24. Ly Cong Uan (1010-1028) then founded the Ly dynasty (1009-1225) with the royal name of Ly Thai To (Thuan Thien). When he was three years old, he was adopted by Van Hanh, a monk because his mother was believed to have been impregnated in a dream by a wizard while on her way to the temple to pray. Van Hanh was a military commander in the Early Le dynasty. After the death of its last heir, several high officials and the monks conspired to install Ly Cong Uan as king. The new king shifted the capital to Dai La which was then known as Thang Long (Hanoi today). ${ }^{36}$

In 1016, China appointed Ly Cong Uan as Jinghai Junjie Dushi (Jingha's Military Commissioner). He was also crowned Giao Chi Quan Vuong with the title Nam Binh Vuong (The King of the Pacified South). ${ }^{37}$ In 1028, for the first time, China even responded by sending to Vietnam (read: Dai Viet大越) tributes which included a set of royal robes and currency. ${ }^{38}$ The approach taken by the Song dynasty was 
obviously different from previously. As stated by Li Shengwei that it had shown more initiative in recognizing Ly's political power based on the reality of the situation then. The change in attitude was also reflected in the Song dynasty's change of heart about reclaiming Vietnam. Instead, it opted for the tributary system as its policy towards the country. ${ }^{39}$

When Ly Thai To died, his heir, Ly Phat Ma (1028-1054) broke the news to Emperor Song Rezong (1023-1063) who sent out emissaries lead by Wang Wei to Vietnam to pay their respects to the late ruler. China also bestowed on him the posthumous title of Than Vu Hoang De.

\section{Song-ly Tributary Terms and Rationale}

China-Vietnam's tributary relations during the Song era and the Ly dynasty are of great significance. For the first time China reciprocated the tribute from Vietnam. The deployment of officers from China to attend a funeral ceremony for a deceased king of Vietnam was another first. Thirdly, the title of vuong (king) instead of the previous quan vuong (of noble class) was conferred on the rulers of Vietnam. These three aspects highlighted the drastic changes and impressive progress in their relationship which were unprecedented. ${ }^{40}$ Later, in the reign of Ly Thanh Tong (1054-1072) the relationship of the two countries reached another level when in 1055, Emperor Song Renzong (1023-1063) presented him tributes in the form of daily necessities that were commercially valuable such as 500 yards of various types of silk fabrics, 500 goats, 50 barrels of wine and so on (See Table 2). These goods were far greater in value than those sent by Vietnam to China. In 1054, the name of Vietnam was changed from Dai Co Viet to Dai Viet.

Table 2: Tributes from Vietnam to China during North Song Dynasty.

\begin{tabular}{|c|c|c|}
\hline Year & Tributes & Source \\
\hline \multirow[t]{2}{*}{1046} & 10 elephants & Songshi, (History of the Song Dynasty), Vol. 3: \\
\hline & & $\begin{array}{lcll}\text { Renzong } & \text { (Emperor } & \text { Song } & \text { Renzong). } \\
{[\text { 《宋史》。仁宗三。] }} & & \end{array}$ \\
\hline 1055 & 10 elephants & $\begin{array}{l}\text { Song Hui Yau (Collections of Important } \\
\text { Documents of Song Dynasty), Vol. 4: Fanyi Si. } \\
\text { (Foreign Countries). [《宋会要》。蕃夷四。] }\end{array}$ \\
\hline 1058 & $\begin{array}{l}\text { A couple of } \\
\text { giraffes }\end{array}$ & Ibid. \\
\hline \multirow[t]{2}{*}{1063} & 9 elephants & Songshi (History of the Song Dynasty), Vol. 4: \\
\hline & & $\begin{array}{llll}\text { Renzong } & \text { (Emperor } & \text { Song } & \text { Renzong). } \\
{[《 \text { 宋史》。仁宗三。] }} & & \end{array}$ \\
\hline \multirow[t]{3}{*}{1081} & $\begin{array}{lr}56 & \text { children } \\
\text { to } & \text { be }\end{array}$ & $\begin{array}{l}\text { Zizhi Tongjian Changbian Jishi Benmo } \\
\text { (Comprehensive Mirror for Aid in Government), }\end{array}$ \\
\hline & servants and & Vol. 315. \\
\hline & $\begin{array}{l}\text { maids in the } \\
\text { palace }\end{array}$ & [《资治通鉴长编纪事本末》。卷三百十五。] \\
\hline
\end{tabular}


Unfortunately, during Ly Nhan Tong's (1072-1128) reign, tension brewed between Vietnam and China for a while. Ly Nhan Tong's military invaded China's border and seized Qinzhou, Lianzhou (now Hepu in Guangdong) and Yongzhou following his fervent attack on Champa. ${ }^{41}$ In 1075, Wang Anshi (王安石, 1021-1086), the prime minister of the Song dynasty informed the emperor of the decline of the Dai Viet's government (Vietnam) after it was defeated by Champa. Since Dai Viet had only the strength of 10 thousand soldiers, it was a golden opportunity for China to oust the Ly dynasty from the common China-Vietnam border where chaos broke out from time to time according to Wang Anshi. ${ }^{42}$

Consequently, the Song emperor instructed Guo Kui to capture Vietnam because Ly Nhan Tong had ignored all the warnings given. Besides mobilizing his troops, the Chinese emperor passed a decree to forbid all the provinces to trade with Dai Viet. Upon hearing the news, the Ly ruler sent Ly Thuong Kiet and Ton Dan with more than 100,000 troops to China to carry out a pre-emptive attack on the Song troops. In the ensuing 40-day battle near Yongzhou (modern-day Nanning), the Dai Viet troops were victorious, capturing the generals of three Song dynasty's armies. ${ }^{43}$ In 1076, the Song emperor formed an alliance with the Champa king before invading Dai Viet. Ly Nhan Tong again sent Ly Thuong Kiet (1019-1105), who proved that he was one of the many great military strategists of Vietnam. He placed spikes under the Nhu Nguyet River before tricking the Song dynasty troops into the deadly trap, killing more than 1,000 Song soldiers and forcing the defeated army to retreat from Dai Viet. The conflict was finally settled when Ly Nhan Tong sent emissaries to seek reconciliation with the Song dynasty. After the death of Ly Than Ton (1128-1138), in the era of Ly Anh Ton (1138-1175), the Song ruler changed the name of Vietnam from Jiaozhi (Giao Chi) to Annan (Annam). In 1164, Emperor Song Xiaozong (1163-1189) declared Ly Anh Ton as King of Annam. ${ }^{44}$

These developments showed that China believed in integrity (wangdao王道, Kingly Way of Governance or Kingly Way) as the core of a diplomatic relationship. ${ }^{45}$ Embracing Confucius' belief of peace, China also welcomed (Vietnamese) emissaries. Niu Junkai argues that Vietnam had created a bond with the Song dynasty that relied on the abundance of China's culture and civilization. ${ }^{46}$

\section{Social and Cultural Impact of Song Era on Vietnamese Ly Dynasty}

The influence of Chinese culture can be seen when the Ly dynasty adapted Confucianism in its administrative structure such as in the centralization of power and the introduction of a tax and a legal system modelled on China's. For the first time in Vietnamese history, Ly Can Duc (1072-1128) introduced an examination system for civil servants based on China's syllabus, covering Chinese history, literature and classical studies in $1075 .{ }^{47}$ According to Truong Buu Lam, such a measure was taken to select court officials and administrators who could strengthen the administration of the Ly dynasty in its efforts to build a new Vietnam. ${ }^{48}$ Then, came the Mandarin classes that created court officials and moral leaders among the Vietnamese civilians. Throughout the Ly dynasty, as many as 27 jinshi (metropolitan graduates) were appointed from four public exams which had been carried out. ${ }^{49}$ According to Yu Yan, these mandarins of the higher hierarchy would influence the formulation of government policies as opposed to the role of the middle class of mandarins who were to contribute mainly towards the implementation or realization of the policies. ${ }^{50}$ In this way, Confucianism had permeated every aspect of the people's lives and the government's administration. ${ }^{51}$ 
The relationship between China and Vietnam was greatly geared towards strengthening the status of Mahayana Buddhism as the official religion and the teachings of Buddha reached its golden age in the era of the Ly dynasty. ${ }^{52}$ The religious figures acted as the Quoc Su (main advisors) who arranged the Ly kings' administrative affairs. ${ }^{53}$ For example, Ly Phat Ma (1005-1054) brought in classic texts of Mahayana Buddhism from China and tried to influence the Vietnamese to accept Buddhism while many monks from China like Cao Tang who founded Thao Duong (Cao Tang Temple) had received support from him. 150 temples were built in the area of Thang Long. Among them were the Xintian Yusi (Temple of the Flourish Heaven) and Wufeng Xingluo (Temple of Five Phoenixes Stars). ${ }^{54}$

Meanwhile, Ly Thanh Tong (1054-1072), influenced by Taoist belief and Confucianism, built Van Mieu (the Temple of Literature) which according to him, was to sharpen the people's minds. He also built idols of Zhou Gong (Duke of Zhou), Confucius and 72 sages for the people to worship. ${ }^{55}$ Le Thanh Khoi and Nguyen Van Que believe that during the governance of the Ly dynasty (1009-1028), Vietnam was immersed deeply in Chinese culture even more so than before. ${ }^{56}$ Their view is also supported by Alexander Woodside who claims that in the $11^{\text {th }}$ century, the traces of Chinese culture were present in every aspect of life in Vietnam. ${ }^{57}$

However, the internal political struggle that was rife resulted in popular rebellion against the Ly dynasty. This situation was exploited by Tran Thu Do, a senior minister of the Ly government who insisted that the queen Ly Chieu Hoang, who was in power, should surrender the throne to Tran Thai Tong (1225-1258). Finally, in 1225, Tran Thai Tong founded the Tran dynasty (1225-1400) which replaced the Ly dynasty in Vietnam. ${ }^{58}$

\section{Conclusion}

Vietnam forged its own social civilisation and local order once it had separated from China. However, the influence and pressure from China was still felt in Vietnam because its history was closely linked to that of China. In foreign relations with the Song dynasty, Vietnam during the Dinh, Le and Ly dynasties was just a vassal state, although at its zenith, it had sent troops into Chinese territory to fight the Song dynasty overlord. The Sino-Vietnamese tributary system played a significant role in their traditional relations, both politically and diplomatically. This tributary relationship of Vietnam as an independent state with China began during the Song dynasty. It became a formal Sino-Vietnamese diplomatic connection. Vietnam's frequent tribute activities and the Song's bestowal of titles were accompanied by occasional wars. Tribute, intertwined with wars, continued for several hundred years from the Song era during which, successive dynastic changes occurred in Vietnam.

However, this tributary connection was sustained because the rulers of Vietnam adhered to China's World Order by seeking Chinese approval and title bestowal to lay a strong foundation for their reign as soon as they ascended to the throne. They needed the political support of China to enhance their position within the country to thoroughly convince the local population of their validity as rulers. That is why Vietnam's rulers of the Dinh, Le and Ly dynasties had not failed to beseech title conferment from China soon after their authority was established. Tributes to China were fervently dispatched to the Song dynasty in acknowledgement of its suzerainty. China also stood to benefit from this tributary arrangement because it reinforced its suzerain position and illustrious status as the 'Heavenly Kingdom'. Acting within the tributary framework, Song China, as the overlord of Vietnam, appeared to have let the Dinh, Le and Ly 
dynasties off rather lightly for being involved in the domestic political tussle for power. The Song emperor had good reasons for doing so. He actually needed time to unite his people from within and strengthen his military power from without in the face of threat from its formidable opponent, in the north, which is Champa. Hampered by these constraints, the Song dynasty was forced to let Vietnam alone for the time being. He also needed breathing space to recoup his strength to deal with the setback. In the meantime, the Dinh. Le and Ly dynasties, in order to safeguard itself, had continued its agenda of sending tributes to China to maintain their tributary relationship, giving the Song dynasty no cause to reassert its control over Vietnam as a colony.

\section{Nota}

1. Joseph Buttinger, The Smaller Dragon: A Political History of Vietnam, New York: Frederick A . Praeger Incp., 1962. pp. 177-178, lists the major rebellions against Chinese rule between the first and the tenth centuries.

2. In 111 BC Vietnam kingdom was annexed by the Han Empire and governed as a Chinese colony, known as Giao Chi (交趾from AD 203). It remained in China's orbit until AD 939. See Tran MyVan, A Vietnamese Royal Exile in Japan: Prince Cuong De (1882-1951), New York: Routledge, 2005, p. 9.

3. An Nam Chi Luoc (The Concise Records of Annam) [ 《安南志略》。] See also Dai Viet Su Ky Toan $T h u$ (Complete History of Dai Viet). [《大越史記全书》。]

4. Vietnam (read Thap Nhi Su Quan十二使君) know as 'Twelve Warlords' was covering two decades (945-967) including the end of Ngo Dynasty (939-965), after the death of King Ngo Quyen (938944). Vietnam was split into twelve regions dominated by military leaders during this period. The term su-quan means 'envoy' but its use at this time corresponds to functions of a warlord or military ruler, whether or not they were supposedly sent to rule the area. See Hugh Dyson Walker, East Asia: A New History, Bloomington: Author House, 2012, p. 210. See also Keith. W. Taylor, "The Twelve Lords in Tenth-Century Vietnam," Journal of Southeast Asian Studies, Vol. XIV, No. 1, March 1983, p. 46.

5. Ye Shaofei, "Shi shiji Yuenan Lishi Zhong De 'Shier Shi Jun' Wenti Kao Lun”, (A Study of the 'Twelve Lords' during $10^{\text {th }}$ Century in the History of Vietnam), in Dui Wenyu (Ed) Tang Shi Lun Cong (The History of Tang Dynasty), Xi'an: San Qin Chubanshe, 2018, p. 330 [ 叶少飞 《十世纪越南历史中的“十二使君”问题考论》。

杜文玉 (主编)。《唐史论丛》。西安 : 三秦出版社]

6. Dai Viet Su Ky Toan Thu, Ban Ky (Basic Annals), Vol. 1: Dinh Ky (Record of the Dinh Dynasty). [《大越史记全书本纪》。卷一：丁纪。]

7. Songshi (History of the Song Dynasty), Vol. 1: Taizu Benji (Basic Annals of Emperor Song Taizu). [《宋史。一：本紀》。[《交趾郡王》。].

8. Dai Viet Su Ky Toan Thu, Ban Ky (Basic Annals), Vol. 1: Dinh Ky (Record of the Dinh Dynasty) and see also Songshi (History of the Song Dynasty), Vol. 488, Lie Zhuan (Collective Biographies), No. 247, Waiguo Shi: Jiaozhi (Foreign Countries 4: Giao Chi). [《宋史》。卷四百八十八：列传第二百四十七。外国四：交趾。]

9. Brantly Womack, China Among Unequals: Asymmetric Foreign Relations in Asia, Singapore: World Scientific Publishing, 2010, p. 193.

10. Songshi (History of the Song Dynasty), Vol. 488, Lie Zhuan (Collective Biographies), No. 247, Waiguo Shi: Jiaozhi (Foreign Countries 4: Giao Chi).

11. Ibid.

12. Ibid. and see also Dai Viet Su Ky Toan Thu, Ban Ky (Basic Annals), Vol. 1: Dinh Ky (Record of the Dinh Dynasty). 
13. In "Tributary System in Xia Dynasty", the Classic of History. See a parallel text at http://chinese.dsturgeon.net/text.pl?node=21107\&if=en. Retrieved date 13 March 2018.

14. Yongtao Du, The Order of Places: Translocal Practices of the Huizhou Merchants in Late Imperial China, Leiden: Brill, 2015, p. 205.

15. James A. Anderson, "Frontier Management and Tribute Relations along the Empire's Southern Border: China and Vietnam in the $10^{\text {th }}$ and $11^{\text {th }}$ Centuries," Ph. D Dissertation, University of Washington, 1999, p. 129.

16. Dai Viet Su Ky Toan Thu, Ban Ky (Basic Annals), Vol. 1: Dinh Ky (Record of the Dinh Dynasty). [《大越史记全书本纪》。卷一: 丁纪。]

17. Songshi (History of the Song Dynasty), Vol. 488, Lie Zhuan (Collective Biographies), No. 247, Waiguo Shi: Jiaozhi (Foreign Countries 4: Giao Chi).

18. Ibid.

19. Ibid. See also Dai Viet Su Ky Toan Thu, Ban Ky (Basic Annals), Vol. 1: Dinh Ky (Record of the Dinh Dynasty). [《大越史记全书本纪》。卷一：丁纪。]

20. The Xu Zizhi Tongjian Changbian (Extended Continuation to Zizhi Tongjian. 《續資治通鑑長編》) was an important book chronicling Chinese history of Northern Song Dynasty between 976-1126. Written by Li Tao (1114-1183).

21. Zi Zhitong Jianchang (Comprehensive Mirror for Aid in Government), Vol. 68: Songji (Record of the Song Dynasty), No. 71. [《續資治通鑑》，卷第六十八：宋纪七十一》。]

22. James Anderson, The Rebel Den of Nung Tri Cao: Loyalty and Identity along the Sino-Vietnamese Frontier, Singapore: NUS Press, 2007, pp. 26-27.

23. Songshi (History of the Song Dynasty), Vol. 488, Lie Zhuan (Collective Biographies), No. 247, Waiguo Shi: Jiaozhi (Foreign Countries 4: Giao Chi).

24. Ibid.

25. See Ye Shaifei, 'Ding Bu Ling, Ding Lian Fuzi Cheng di Kao' (Dinh Bo Linh, Dinh Lien sonfather Proclaimed as Emperor), Song Shi Yanjiu Luncong (Study on the History of Political System during the Song Dynasty), Vol. 1, 2015, pp. 451-487. [叶少飞, 《丁部领、丁琏父子称帝考》。《宋史研究论丛》。]

26. Songshi (History of the Song Dynasty), Vol. 488, Lie Zhuan (Collective Biographies), No. 247, Waiguo Shi: Jiaozhi (Foreign Countries 4: Giao Chi).

27. Ibid.

28. Keith, W. Taylor, "The Twelve Lords in Tenth-Century Vietnam," Journal of Southeast Asian Studies, Vol. XIV, No. 1, March 1983, p. 66.

29. Dai Viet Su Ky Toan Thu, Ban Ky (Basic Annals), Vol. 1: Ly Ky (Record of the Le Dynasty).

30. Songshi (History of the Song Dynasty), Vol. 488, Lie Zhuan (Collective Biographies), No. 247, Waiguo Shi: Jiaozhi (Foreign Countries 4: Giao Chi).

31. Ibid.

32. Songshi (History of the Song Dynasty), Vol. 488, Lie Zhuan (Collective Biographies), No. 247, Waiguo Shi: Jiaozhi (Foreign Countries 4: Giao Chi).

33. Liji (Book of Rites). [《礼记。檀弓上。》] The Book of Rites describes ancient stereotypes about the $S i \mathrm{Yi}$ "Four Barbarians" surrounding China.

34. Songshi (History of the Song Dynasty), Vol. 488, Lie Zhuan (Collective Biographies), No. 247, Waiguo Shi: Jiaozhi (Foreign Countries 4: Giao Chi).

35. Guo Zhenduo \& Zhang Xiaomei (eds.) Yuenan Tongshi (General History of Vietnam), Beijing: Renming Daxue Chubanshe, 2000, 266-267. [ 郭振铎, 张笑梅主编, 《越南通史》, 北京: 人民大学出版社。] Also see Songshi (History of the Song Dynasty), Vol. 488, Lie Zhuan (Collective Biographies), No. 247, Waiguo Shi: Jiaozhi (Foreign Countries 4: Giao Chi).

36. Ibid.

37. Ibid.

38. Dai Viet (大越, literally Great Viet) is the name of Vietnam for the periods from 1054 to 1400 and 1428 to 1804 . 
39. Li Shengwei, "Shilun Songchao yu Yuenan Lichao de Guanxi (China of Song Dynasty and Vietnam of Ly Dynasty Relationship)." Master Thesis, Zhengzhou Daxue (Zhengzhou University). 2005, pp. 12 13. [李胜伟, 《试论宋朝与越南李朝的关系》, 硕士, 郑州大学。]

40. Song Hui Yau (Collections of Important Documents of Song Dynasty), Vol. 4: Fanyi Si. (Foreign Countries). [《宋会要辑稿》。蕃夷四之三三。]

41. Zi Zhitong Jianchang (Comprehensive Mirror for Aid in Government), Vol. 68: Songji (Record of the Song Dynasty), No. 71. [《續資治通鑑》，卷第六十八 : 宋纪七十一》。]

42. While entering Yongzhou (邑州), Vietnam was reported to have killed about 58,000 citizens and thousands more in Qinzhou and Lianzhou. See Dai Viet Su Ky Toan Thu (Complete History of Dai Viet), Quyen Nhi (Vol. 2), Ly Ky (Annal of the Ly Dynasty). [《大越史记全书本纪》。卷二：李纪。]

43. Song Hui Yau (Collections of Important Documents of Song Dynasty), Vol. 4: Fanyi Si (Foreign Countries). [《宋会要辑稿》。蕃夷四之三三。]

44. Songshi (History of the Song Dynasty), Vol. 488, Lie Zhuan (Collective Biographies), No. 247, Waiguo Shi: Jiaozhi (Foreign Countries 4: Giao Chi).

45. Satoshi Amako, "China's Diplomatic Philosophy and View of the International Order in the 21st Century", Journal of Contemporary East Asia Studies, 3:2, 2014, pp. 29-30.

46. Niu Junkai, "Zhaogong yu Bangjiao: Mingmo Qingchu Zhongyue Juanxi Yanjiu”, Ph.D Dissertation, University of Zhongshan, 2003. [ 牛军凯, 《朝贡与邦交: 明末清初中越关系研究 (15931702)》, 中山大学博士学位论文。]

47. Zi Zhitong Jianchang (Comprehensive Mirror for Aid in Government), Vol. 68: Songji (Record of the Song Dynasty), No. 71. [《續資治通鑑》，卷第六十八 : 宋纪七十一》。]

48. Truong Buu Lam, New Lamps for Old: The Transformation of the Vietnamese Administrative Elite, Singapore: Institute of Southeast Asian Studies, 1982, p. 6.

49. Dai Viet Su Ky Toan Thu (Complete History of Dai Viet), Ban Ky Quyen Ngu (Basic Annal), Vol.3: Ly $K y$ (Annals of the Ly Dynasty). [《大越史记全书》。本纪卷3：李聖宗纪。]

50. Yu Yan, "Qingdai Zhongyue Shijie Yanjiu (The Study on the Envoys between China and Vietnam in Qing Dynasty)", Master Thesis, Shandong University, 2007, p. 36. [于燕, 《清代中越使节研究》, 硕士学位论文, 山东大学。].

51. Huang Min, "Evolution of Imperial Civil Examination in Vietnam and Its Positive Influence on Vietnamese Culture," Journal of OLA University of Foreign Languages, Vol. 26, No. 6, November 2003, pp. 104-105.

[黄敏, 《科举制度在越南的嬗变及其对越南文化的积极影响》, 《解放军外国语学院学报》 。]

52. Guo Zhenduo \& Zhang Xiaomei (eds.) Yuenan Tongshi (General History of Vietnam), Beijing: Renming Daxue Chubanshe, 2000, pp. 272-276. [郭振铎, 张笑梅主编, 《越南通史》, 北京: 人民大学出版社。]

53. Nguyen The Anh, "From Indra to Maitreya: Buddhist Influence in Vietnamese Political Thought," Journal of Southeast Asian Studies, Vol.33, No. 2, Singapore, Jun 2002, pp. 225-241.

54. Iwamura Shigemitsu, Annan Tsushi (General History of Annam), trans. Xu Yunqiao, Singapore: $\begin{array}{lllll}\text { Xingzhou } & \text { Shijie } & \text { Shuju, } & 1957, & \text { p. }\end{array}$ [岩村成允, 許雲樵譯, 《安南通史》, 星洲：星洲世界书书局。]

55. Dai Viet Su Ky Toan Thu (Complete History of Dai Viet), Ban Ky Quyen Ngu (Basic Annal) Vol.3: Ly Ky (Annals of the Ly Dynasty).

56. See Le Thanh Khoi 1995. Le Vietnam, Histoire et Civilization (Vietnam, History and Civilization), Paris: Les Editions de Minuit and Nguyen Van Que, Histoire des Pays de l'Union Indochinoise Vietnam, Cambodge, Laos (History of the countries of the Union of Indochina Vietnam, Cambodia, Laos), Saigon, 1932.

57. Alexander Woodside, "Vietnamese History: Confucianism, Colonialism, and the Struggle for Independence," Vietnam Forum 11, Winter-Spring, 1988, pp. 21-48.

58. Dai Viet Su Ky Toan Thu (Complete History of Dai Viet), Ban Ky Quyen Ngu (Basic Annal) Vol. 6: Tran Ky (Annals of the Tran Dynasty). [《大越史记全书》。本纪卷六: 陈记。] 